\title{
Comparison Between Conditions of Major Roads Within and Outside the Port of Durban
}

\author{
Oscar Kunene \\ Durban University of Technology \\ Durban, South Africa \\ mbongenik@yahoo.com
}

\author{
Dhiren Allopi \\ Durban University of Technology \\ Durban, South Africa \\ allopid@dut.ac.za
}

\begin{abstract}
Over the past years road traffic has increased at the Port of Durban. Due to the lack of maintenance, this has resulted in road deterioration. Roads are considered as the most important transport mode at the Port of Durban. It is an important mean for facilitating economic growth of local, regional and national industries. For the Port to maintain global competitiveness with the current trend of globalization, it has to be ensured that the roads are well maintained. The purpose of the paper is to provide an overview of road condition within and outside the Port. Verification and assessment of the condition of the existing eight major roads was conducted. Comparisons between the condition of the eight major roads within and outside the Port were highlighted. Conclusions and recommendations were also drawn based on the findings.
\end{abstract}

Keywords-road condition; verification; assessment; Pavement Management System; Port of Durban

\section{INTRODUCTION}

\section{A. Background of the study}

In the past, all roads within the Port of Durban were owned and maintained by Transnet National Ports Authority (TNPA, formerly known as Portnet). Currently, not all roads within the Port are owned and maintained by TNPA, e.g. public roads (eThekwini Municipality) and access roads to private terminals (lessees). Some roads are divided into two, with one section of the road falling within the Port boundary and another section falling outside the Port boundary. These roads are maintained by both TNPA and eThekwini Municipality. TNPA is the landlord for the Port of Durban. Private companies and other Transnet divisions such as Transnet Port Terminals and Transnet Freight Rail leases land from TNPA. EThekwini Municipality is the local government for the City of Durban, in which the Port of Durban is located.

In the eighty five years leading up to 1995, the South African Railways and Harbours held a monopoly on transport over a $50 \mathrm{~km}$ lead distance from the port and therefore all cargo owners, both import and export, were obliged to dispatch their products by rail. This led to large areas of the Bayhead becoming the preserve of the railways and large marshalling yards and carriage and wagon workshops were established in the area. When rail was the dominant mode of transport to the port, all the marshalling yards were used and, in fact, the lack of marshalling space often proved to be the bottleneck of the Port [1].

In the last fifteen years, with the deregulation of road transport, there was an immediate and extensive switch of general cargo from rail to road transport with the current split being close to $80 \%$ road and $20 \%$ rail. The result of this switch has placed tremendous pressure on the road network while railway facilities are now greatly under-utilised and the usage of this prime space needs to be incorporated into the future planning of the port [1].

Based on service level agreement for eThekwini Municipality, highlighting response time for road maintenance, the reasonable time for repair of potholes is within 48 hours, sink hole and traffic signals are within 24 hours, road, sidewalk repairs, reinstatements of trenches, broken kerbs and road signs are repaired within 10 days [2].

\section{B. Objectives of the study}

The main purpose of the study was to determine the following:

- To compare the condition of roads within and outside the Port which are owned by different authorities.

- To identify and assess the condition of the eight major roads within and outside the Port.

- To determine factors that affect road condition.

- To recommend measures based on the findings.

\section{Study limitations}

The study focuses on comparisons between conditions of roads within and outside the Port of Durban. It covers the eight major roads which are main accesses to the Port of Durban. Figure 1 shows the eight major roads within the Port of Durban that connect the South, West and North of eThekwini Municipality. These roads are Bayhead, Quayside, Maydon, Rick Turner (formerly known as Francois road), Wisely, South Coast, Bluff and Iran Roads. Sections of these roads extend outside the Port boundary. All roads highlighted in dotted lines are sections of the roads outside the Port. 


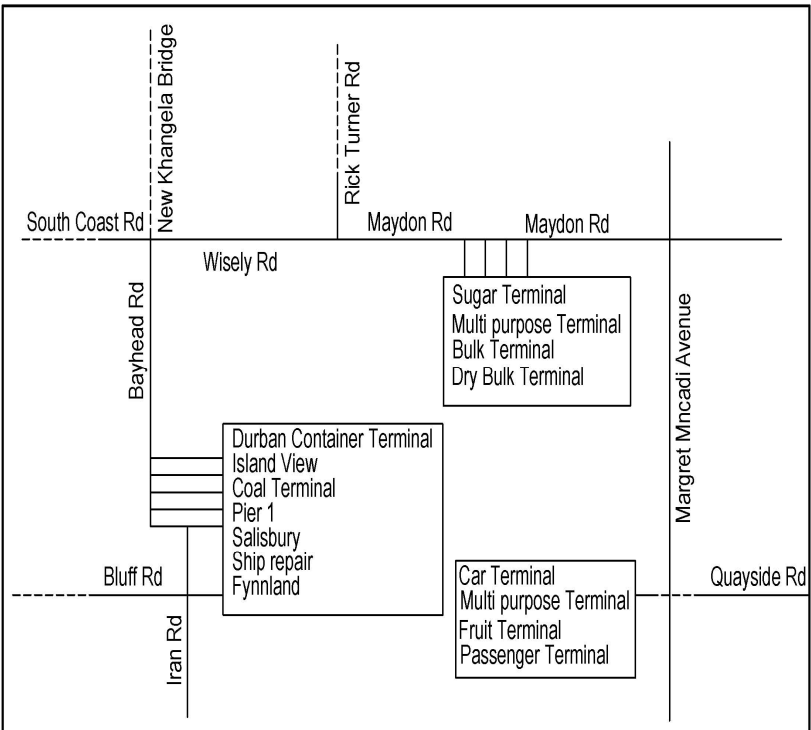

Fig. 1. Road Network inside and outside Port of Durban.

\section{Methodology}

The Pavement Management System Manual was used as a reference for physical site measurements conducted as part of the assets verification process. Verification and assessment were conducted as per Table I.

TABLE I. SCHEDULE OF VERIFICATION AND ASSESSMENTS

\begin{tabular}{|c|c|c|c|c|}
\hline $\begin{array}{c}\text { Road } \\
\text { name }\end{array}$ & $\begin{array}{c}\text { Date of } \\
\text { survey }\end{array}$ & $\begin{array}{c}\text { Length } \\
\text { within Port } \\
\mathbf{( k m )}\end{array}$ & $\begin{array}{c}\text { Length } \\
\text { outside } \\
\text { Port } \\
\text { (km) }\end{array}$ & $\begin{array}{c}\text { Number of } \\
\text { lanes in } \\
\text { each } \\
\text { direction }\end{array}$ \\
\hline Quayside & $25 / 10 / 2011$ & 3 & 0.3 & 1 \\
\hline Maydon & $27 / 10 / 2011$ & 2.4 & 0 & 1 \\
\hline $\begin{array}{c}\text { Rick } \\
\text { Turner }\end{array}$ & $01 / 11 / 2011$ & 0.4 & 4 & 1 \\
\hline Wisely & $01 / 11 / 2011$ & 0.6 & 0 & 2 \\
\hline Bayhead & $03 / 11 / 2011$ & 5 & 0.5 & 2 \\
\hline $\begin{array}{c}\text { South } \\
\text { Coast }\end{array}$ & $03 / 11 / 2011$ & 2.3 & 7 & 1 \\
\hline Bluff & $10 / 11 / 2011$ & 2.4 & 6 & 1 \\
\hline Iran & $10 / 11 / 2011$ & 1.6 & 0 & 1 \\
\hline
\end{tabular}

Note: The full length of roads such as Maydon, Wisely and Iran Roads falls within the port. Bayhead, Quayside, Rick Turner, South Coast and Bluff Road are divided into two sections. The measurements recorded represent the section of roads within and outside the Port.

The visual inspection (eyeball method) was identified for assessing the condition of the road infrastructure. This method is a quick visual inspection of the road on a routine basis to identify problems. The visual inspections were conducted on all eight major roads within the Port and section of roads outside the Port. The comparison between the roads within and outside the Port was also conducted.

During the visual inspection of each road, an inspection report was compiled which included the following components: road markings, traffic signs, potholes, cracks, rutting, aggregate loss, riding quality, surface drainage and unpaved shoulders. Each component was rated using the following rating method in Table II:

TABLE II. RATING METHOD [3]

\begin{tabular}{|c|c|c|l|}
\hline Percentage & Description & Rating & \multicolumn{1}{|c|}{ Detailed description } \\
\hline $100-90 \%$ & Excellent & A & $\begin{array}{l}\text { It is new and perfect. No } \\
\text { maintenance work required at this } \\
\text { stage }\end{array}$ \\
\hline $89-70 \%$ & Very good & B & $\begin{array}{l}\text { It looks like new and minor } \\
\text { maintenance work may be required } \\
\text { at a later stage }\end{array}$ \\
\hline $69-50 \%$ & Good & C & $\begin{array}{l}\text { It is moderate and maintenance } \\
\text { work may be required within 12 } \\
\text { months }\end{array}$ \\
\hline $49-30 \%$ & Fair & D & $\begin{array}{l}\text { It is reasonable but maintenance } \\
\text { work may be required within } 6 \\
\text { months }\end{array}$ \\
\hline $29 \%-10 \%$ & Poor & E & $\begin{array}{l}\text { It is not safe and need urgent } \\
\text { attention }\end{array}$ \\
\hline $9 \%-0 \%$ & Very poor & F & $\begin{array}{l}\text { It is very poor and reconstruction } \\
\text { work required urgently }\end{array}$ \\
\hline
\end{tabular}

The findings of the assessment for the eight major roads within and outside the Port (where applicable) were recorded on inspection reports. Table III shows an example of an inspection report that was conducted on section of Bayhead Road within the Port:

TABLE III. INSPECTION REPORT CONDUCTED ON BAYHEAD ROAD

\begin{tabular}{|c|c|c|c|}
\hline Component & Weight & Rating & $\begin{array}{c}\text { Weighted } \\
\text { Average }\end{array}$ \\
\hline Road markings & 10 & $65 \%$ & 6.5 \\
\hline Traffic signs & 10 & $65 \%$ & 6.5 \\
\hline Potholes & 20 & $45 \%$ & 9 \\
\hline Cracks & 10 & $45 \%$ & 4.5 \\
\hline Rutting & 10 & $45 \%$ & 4.5 \\
\hline Aggregate loss & 10 & $45 \%$ & 4.5 \\
\hline Riding quality & 10 & $50 \%$ & 5.0 \\
\hline Surface drainage & 15 & $45 \%$ & 6.75 \\
\hline $\begin{array}{c}\text { Unpaved } \\
\text { shoulders }\end{array}$ & 5 & $65 \%$ & 3.25 \\
\hline TOTAL & $\mathbf{1 0 0}$ & & $\mathbf{5 0 . 5}$ \\
\hline
\end{tabular}

The weighting of each component was identified based on the importance and damage that can be caused if that particular component was not repaired. Rating score was based on the condition of the component and Table II was used during the rating process.

\section{RESULTS}

The results from the inspection reports conducted on the eight major roads within the Port are shown in Figure 2. Maydon and South Coast Roads are low rated roads which are in a poor condition. Quayside Road is highly rated and in a very good condition. 


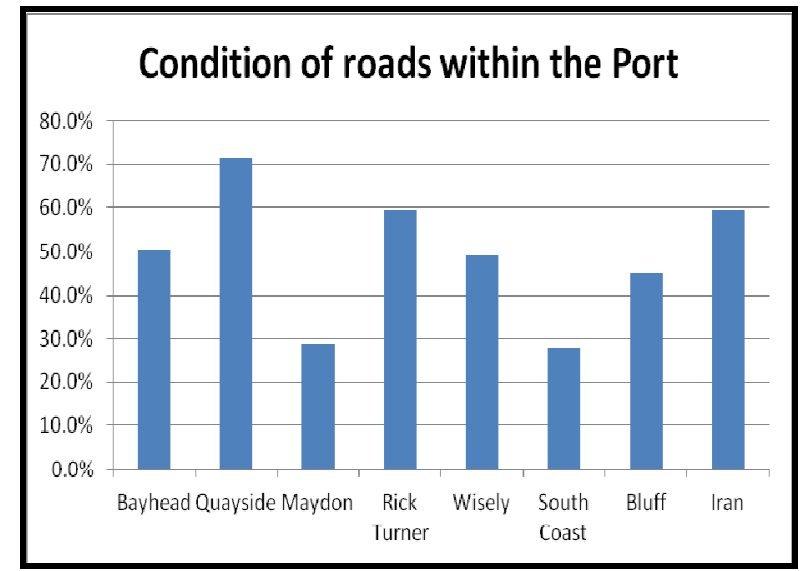

Fig. 2. Summary of major road condition within the Port

The following are results obtained during the assessment of roads within the Port:

- Quayside Road (71.5\%) falls under B (very good) category. It looks like new and minor maintenance work may be required at a later stage.

- $\quad$ Rick Turner (59.5\%), Iran Road (59.5\%) and Bayhead Road $(50.5 \%)$ fall under C (good) category. It is moderate and maintenance work may be required within 12 months.

- Wisely Road (49\%) and Bluff Road (45\%) fall under D (fair) category. It is reasonable but maintenance work may be required within 6 months.

- Maydon Road (28.8\%) and South Coast Road (28\%) fall under $\mathrm{E}$ (poor) category. It is not safe and needs urgent attention.

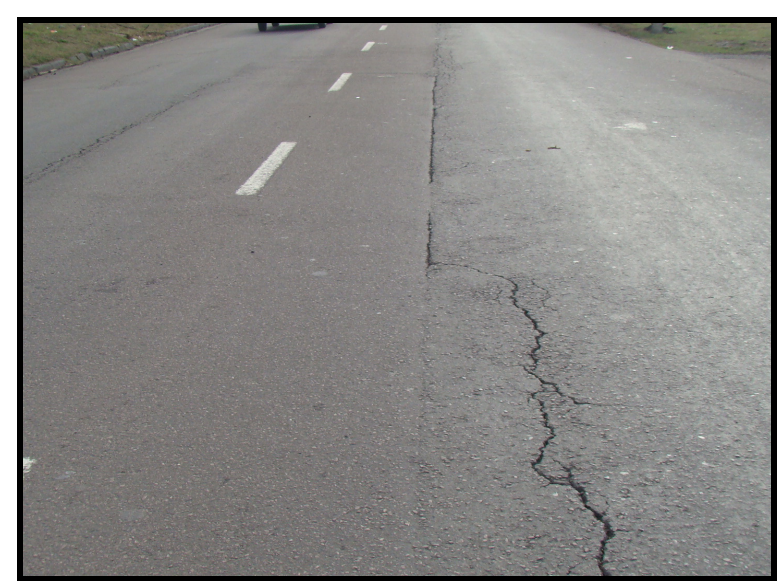

Fig. 3. Longitudinal and crocodile cracks on South Coast Road

Figure 3 shows the longitudinal cracks found on sections of Bayhead Road within the Port where the asphalt layer failed at the joint.

The results from the inspection reports conducted at the five major roads that have sections which fall outside the Port are shown in Figure 4, namely Bayhead, Quayside, Rick Turner,
South Coast and Bluff Roads. The full length of Maydon, Wisely and Iran Road falls within the Port and hence cannot be assessed. South Coast Road is a low rated road which is in a fair condition and all other roads are rated above $70 \%$.

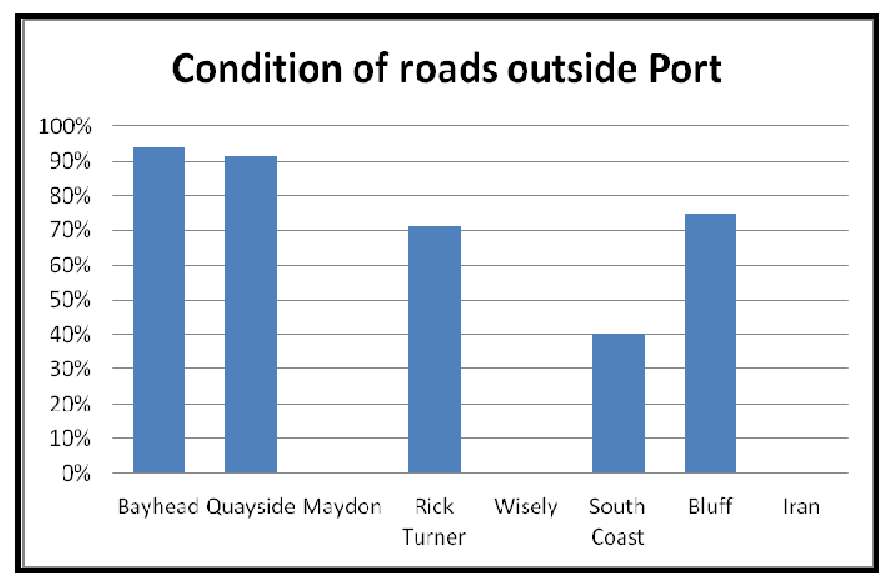

Fig. 4. Assessment of road condition outside of the Port.

The following are results obtained during the assessment of roads outside the Port:

- $\quad$ Bayhead (94\%) and Quayside Road (91.5\%) fall under A (excellent) category. It is new and perfect. No maintenance work required at this stage.

- $\quad$ Rick Turner (71\%) and Bluff Road (75\%) fall under B (very good) category. It looks like new and minor maintenance work may be required at the later stage.

- South Coast Road (40\%) falls under D (fair) category. It is reasonable but maintenance work may be required within 6 months.

Figure 5 shows the typical defects found on sections of Rick Turner Road outside the Port near King Edward Hospital.

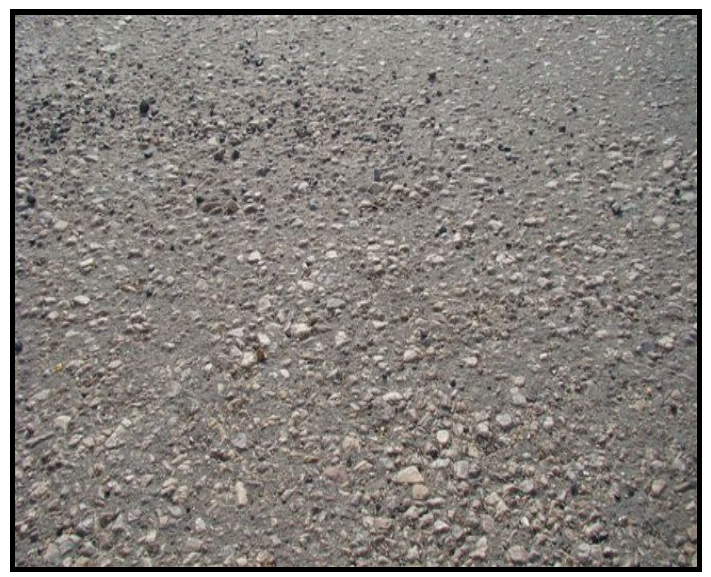

Fig. 5. Aggregates loss on Rick Turner Road.

The section of roads which falls outside the Port are in a good condition compared to the section of roads within the Port as shown in Figure 6. 


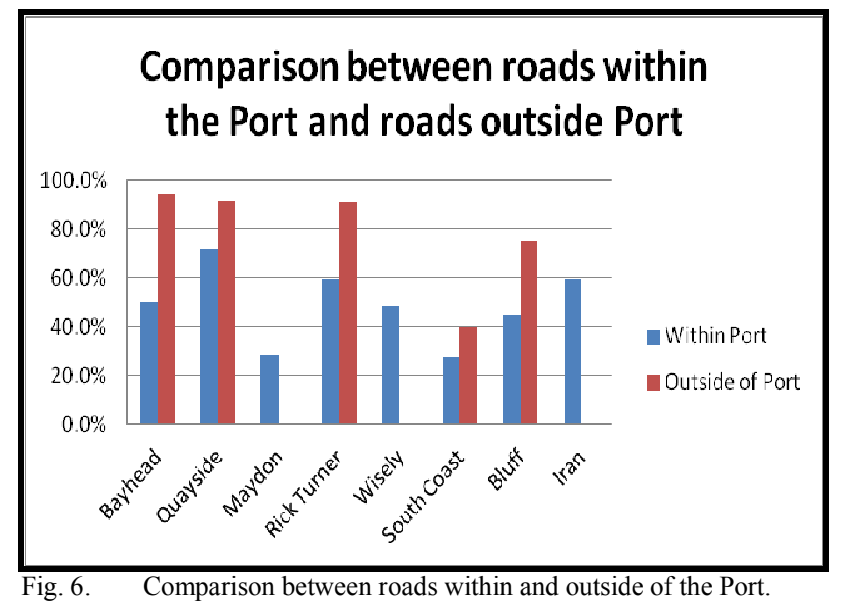

\section{FACTORS AFFECTING ROAD CONDITIONS}

There are a number of factors that contribute to poor condition of roads within the Port of Durban such as:

- Growth of container cargo

- Increase in the dimension and weight of trucks

- Transport deregulation over the past years and overloading

A brief discussion on each factor is highlighted:

\section{A. Growth of container cargo}

The Port of Durban has been experiencing high growth rate in container traffic which impacts on road infrastructure condition. About $70 \%$ of South African container cargos are handled at the Port of Durban. The Port of Durban has a dedicated Container Terminal that handles 2,7 million Twenty Foot Equivalent Units (TEU) per annum. Average growth of container volumes over the past few years is between $5-7 \%$ per annum.

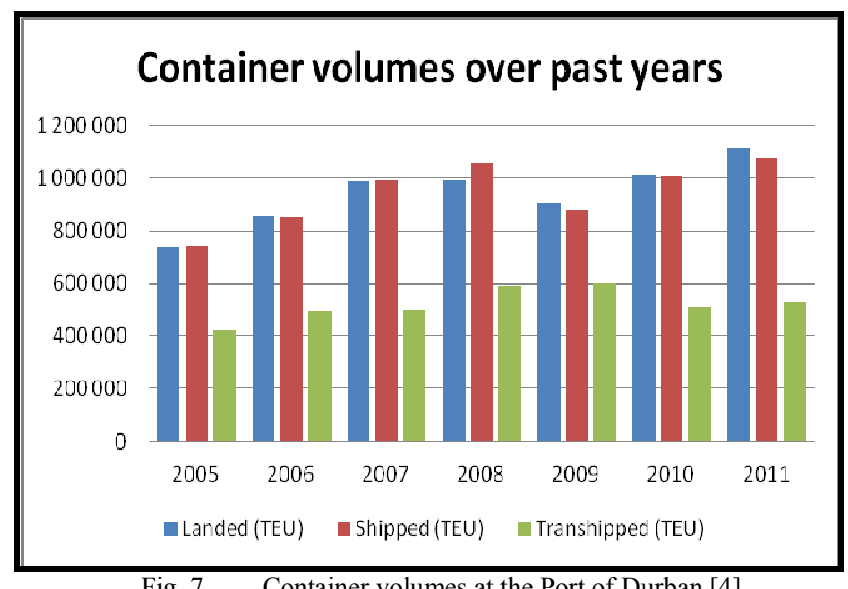

Fig. 7. Container volumes at the Port of Durban [4]

Figure 7 shows the container volumes handled at the Port of Durban over the years where it increased from 1,9 million TEU in year 2005 to 2,7 million TEU in year 2011. This has put pressure on the roads within the Port and resulted in deterioration of the road condition [4].

\section{B. Increase in dimension and weight of trucks}

There has been an increase in the dimension and weight of trucks over the years. The overall length of trucks has increased rapidly from $13 \mathrm{~m}$ in 1960 to $22 \mathrm{~m}$ in 1996, which is currently used these days, that is almost double. The weight, which is gross combination mass (GCM) has increased from 38000 tons to 58800 tons. These changes in dimensions and weight of trucks have resulted due to global modification of trucks capacity. These changes have major impact on road condition at the Port of Durban [5].

The history of the trucks dimensions and weight are as follows:

- In 1970: Overall length of truck increased from $13 \mathrm{~m}$ to $17 \mathrm{~m}$. Gross combination mass increased from 38000 tons to 41020 tons.

- In 1980: Overall length of truck increased from $17 \mathrm{~m}$ to $20 \mathrm{~m}$. Gross combination mass increased from 41020 tons to 47007 tons.

- In 1990: Overall length of truck increased from $20 \mathrm{~m}$ to $22 \mathrm{~m}$. Gross combination mass increased from 47007 tons to 56000 tons.

- In 1996: Overall length of truck remains at $22 \mathrm{~m}$. Gross combination mass increased from 56000 tons to 58800 tons with $5 \%$ overload allowance [6].

\section{Transport deregulation over the past years and overloading}

By the 1970's, government realized that transport deregulation was necessary and that the railway administration would have to be relieved of its former social obligations (i.e. transport of uneconomic traffic or on money-losing branches and secondary lines and passenger services in general). The form of transport deregulation was debated for another ten years. By 1989 de-facto deregulation had taken place [7].

A Government White Paper on Transport was published in 1991. While specific issues were identified, consensus could not be reached on implementing necessary control mechanisms such as the Road Traffic Quality System (RTQS) and how fair and equitable road-user fees could be levied to the different size motor vehicles. But the legislation was enacted, the Road Permit system abolished, and a transport "free-for-all" was allowed to develop [7].

Government enacted further legislation, while the Department of Transport unilaterally changed existing statutes, which resulted in larger heavy vehicles appearing on the highways. Axle loads were increased, the Bridge formula relaxed, but the RTQS was not implemented. Competition within the road industry - and not just against rail - led to price cutting, overloading, un-roadworthy vehicles and excessive pressure on truck drivers to work long and uncontrolled hours [7]. 
Enforcement is a particular issue in the area of truck overloading, where some haulers are able to improve their costs by overloading their vehicles, secure in the knowledge that enforcement will be sporadic at best. While the haulers realize a cost advantage, they create an additional cost in road maintenance and repair. Truck overloading is one of the principal sources of road damage in the country: the $30 \%$ to $40 \%$ of trucks that are overloaded caused $60 \%$ of the damage to the road network [1].

\section{CONCLUSIONS AND RECOMMENDITIONS}

Maydon and sections of South Coast Roads which falls within the Port are low rated roads and are in a poor condition. These roads are not safe and urgent attention is required. Quayside Road is in a better condition compared to other roads and falls under category B (very good). The section of South Coast Road which falls outside the Port is a low rated road and is in a fair condition.

All sections of roads which fall outside of the Port are owned by eThekwini Municipality and most of these roads are in good condition except for South Coast Road. The public are involved in ensuring that these roads are well maintained by informing eThekwini Municipality via a 24 hour toll free number. Transnet National Ports Authority owns all sections of roads which fall within the Port and they are in a fair condition but much work needs to be done. The public are not well informed on who can assist if there are defects on the road. The major problems are experienced when there is a change of ownership.

It is recommended that these eight major roads have their own budget and assessed separately to other roads because of their importance. The ownership must be clear by installation of boards or signs on each road indicating the owner's name and contact details so that it will be easy for road users to report any defect on any road. Fast track handover period of ownership will ensure that there is continuity in terms of maintenance.

More attention must be paid in terms of regular inspections of roads within the Port in order to improve their standard to be similar to roads outside the Port. It is recommended that the Area Supervisor, Maintenance Manager and Road Engineer for both parties (eThekwini Municipality and Transnet National
Port Authority) conduct visual inspections annually. It is further recommended that problem areas be inspected as often as required. It is recommended that on site or laboratory material testing be conducted as and when there are failures to the base, sub-base and road surface layers (asphalts).

The road freight industry in South Africa needs to be regulated especially on overloading and truck driving hours. Weigh bridges and truck toll fees are possible solutions. Incidences of motor vehicle roadworthiness non compliance have been highlighted by the large number of trucks. Truck driver working hours have also become a major issue that must be addressed urgently. The establishment of a Railway Safety Regulator has set standards for the rail industry but a similar regulator is urgently needed for the road industry.

\section{ACKNOWLEDGMENT}

The author thanks supervisor Professor Dhiren Allopi for his guidance and support throughout the study. Thanks to Transnet National Ports Authority and eThekwini Municipality for allowing me to access their information. Also, the financial support from Durban University of Technology is greatly appreciated.

\section{REFERENCES}

[1] Department of Transport KwaZulu-Natal, National Transport Master Plan 2005-2050, 2008

[2] City of Durban, Standard Engineering Specification, 1992

[3] Transnet National Ports Authority, Port Maintenance Manual, Road Module, 2004

[4] Transnet National Ports Authority, Summary of cargo handled at Ports of South Africa, 2012 [Online] available at: http://www.transnetnationalportsauthority.net/DoingBusinesswithUs/Cal endar\%20years/Calendar\%20Year\%202005.pdf [accessed in October 2012]

[5] H. Ghoos, J. Korsgaard, L. Runge-Schmidt, H. Agerschou, "Berth and Terminal design in general. Storage facilities and cargo handling systems" in Planning and Design of Port Marine Terminal, Thomas Telford, Ltd, 2004

[6] B. Sheat, "Truck dimensions and weight", Railways Africa, Issue 5, pp 13-20, 1997

[7] Road and Rail Association of South Africa, Modal Issues, 2007 [Online] available at: http://www.rra.co.za/?page_id=15738 [accessed in October 2012] 